\title{
"Reflexiones sobre la legalidad y oportunidad del Decreto Ley andaluz 6/2013, de 9 de abril, de medidas para el cumplimiento de la Función Social de la Vivienda"
}

\author{
María del Mar Caraza Cristín \\ Titulada Superior de la Junta de Andalucía y \\ Profesora Asociada de la Universidad de Sevilla
}

\begin{abstract}
SUMARIO: I. INTRODUCGIÓN. II. CONTENIDO DEL DECRETO-LEY 6/2013, DE 9 DE ABRIL. 1. Consideraciones previas sobre el uso del Decreto-Ley. 2. Sobre la suficiencia de las competencias que avalan el Decreto-Ley 6/2013. 3. Principales medidas adoptadas. 4. Sobre la viabilidad de las medidas previstas. III. ANÁLISIS DE OTRAS MEDIDAS EXISTENTES PARA PALIAR LOS DESAHUCIOS. 1. El Real Decreto-Ley 27/2012, de 15 de noviembre, de Medidas Urgentes para reforzar la Protección a los Deudores Hipotecarios. 2. La Sentencia del Tribunal de Justicia de la Unión Europea (Sala Primera), de 14 de marzo de 2013. 3. La Ley 1/2013, de 14 de mayo, de Medidas para reforzar la Protección a los Deudores Hipotecarios, Reestructuración de Deuda y Alquiler Social. 4. El Real Decreto 233/2013, de 5 de abril, por el que se regula el Plan Estatal de fomento del alquiler de viviendas, la rehabilitación edificatoria, y la regeneración y renovación urbanas, 2013-2016. 5. La Ley 4/2013, de 4 de junio, de Medidas de Flexibilización y Fomento del Mercado del Alquiler de Viviendas. IV. CONGLUSIONES.
\end{abstract}

\section{RESUMEN:}

Con base en el argumento de que la propiedad está subordinada al interés general y con el propósito de garantizar el derecho a la vivienda de aquellas personas en especiales circunstancias de emergencia social que se vean afectadas por procesos de ejecución hipotecaria, el Consejo de Gobierno andaluz ha aprobado el Decreto-Ley 6/2013, de 9 de abril. Mediante esta norma se procede a delimitar el contenido esencial del derecho de propiedad de la vivienda y se introduce en el Derecho autonómico andaluz la regulación de nuevas me- 
didas de tipo sancionador y expropiatorio bastante controvertidas, tanto desde un punto de vista jurídico como de oportunidad y conveniencia, sobre todo, si se tiene en cuenta la existencia de otras vías legales y judiciales ya existentes que permiten la consecución del mismo objetivo de manera menos restrictiva y limitadora del derecho a la propiedad.

Palabras claves: Derecho de propiedad. Función social. Vivienda. Vivienda protegida. Expropiación. Desahucios.

\section{ABSTRACT:}

Based on the subordination of individual property right to general interest and intended to guarantee the housing rights of people in special circumstances affected by foreclosure processes, the Decree-Law 6/2003 of April 9 was approved by the Andalusian Government. This law delimits the fundamental of private property in relation to housing and introduces in the Autonomic Law actions as imposing sanctions and property eviction. Indeed, these measures are highly controversial both judicially and by opportunity and convenience, even more taking into account that already existing legal procedures permit to achieve the same objectives in ways that are not so restrictive with individual property right.

Keywords: Property right. Social Function. Housing. Protected Housing. Foreclosures. Eviction.

\section{INTRODUCGIÓN}

Recientemente se publicaba en esta misma Revista un artículo en el analizaba las últimas novedades normativas en materia de vivienda protegida a raíz de la entrada en vigor de la Ley 2/2012, 30 de enero, por la que se modifica la Ley de Ordenación Urbanística de Andalucía ${ }^{1}$.

Comenzaba comentando lo abrumador de la producción normativa existente en esta materia, así como lo cambiante de su sentido, con la carga de in-

\footnotetext{
${ }^{1}$ En él abordaba, entre otras cuestiones, la regulación del derecho a una vivienda, desde su vertiente constitucional y estatutaria, el concepto de vivienda digna, de vivienda protegida y los instrumentos con los que contaba la Administración Pública andaluza para dar efectividad a tal derecho. Vid. "Novedades normativas en materia de vivienda protegida en Andalucía: especial referencia a los Planes Municipales de Vivienda y Suelo", RAAP núm. 83 (mayo-agosto 2012), págs. 331-374.
} 
seguridad jurídica que ello conlleva, no sólo para la ciudadanía, sino para todos los operadores del sector ${ }^{2}$. Pues bien, nueva muestra de ese boom es la publicación en el Boletín Oficial de la Junta de Andalucía número 69, de 11 de abril, del Decreto-Ley 6/2013, de 9 de abril, de medidas para asegurar el cumplimiento de la Función Social de la Vivienda.

El objetivo de esta norma, poner fin al drama de los desahucios y dar efectividad al derecho a una vivienda digna, es absolutamente plausible. Es más, su consecución es deber de los poderes públicos. La cuestión es si el camino adoptado por la Comunidad Autónoma de Andalucía -y parece que, posiblemente, a seguir por otras, tal y como han anunciado Canarias y Cataluña- es el adecuado, oportuno y económicamente viable, fundamentalmente teniendo en cuenta las normas estatales aprobadas en materia de desahucios, alquiler e hipotecas, la sentencia del Tribunal de Justicia de la Unión Europea de 14 de marzo de 2013 que posibilita la suspensión del desahucio y las condiciones contempladas en el Memorándum del rescate bancario impuesto a España desde la Unión Europea.

En definitiva, en las siguientes páginas, sin discutir la legitimidad y bondad de los objetivos perseguidos por el citado Decreto-Ley, pretendo lanzar algunas reflexiones sobre, por una parte, la adecuación y congruencia de los motivos aducidos por el Decreto-Ley 6/2013 y las concretas medidas adoptadas, en especial, la expropiación temporal de viviendas y la potestad de sancionar viviendas desocupadas y, por otra parte, sobre la existencia actual de otras posibles vías más proporcionadas y menos gravosas y restrictivas del derecho fundamental a la propiedad privada.

\footnotetext{
${ }^{2}$ En este sentido, apuntar que el concepto de vivienda protegida se ha visto nuevamente perfilado a nivel de normativa estatal por la Disposición Adicional $3^{\mathrm{a}}$ del Real Decreto 233/2013, de 5 de abril, por el que se regula el Plan Estatal de fomento del alquiler de viviendas, la rehabilitación edificatoria, y la regeneración y renovación urbanas, 2013-2016. Sin perjuicio de las situaciones jurídicas creadas al amparo de anteriores normativas aplicables, se establece que se entenderá por vivienda protegida, "toda aquella que cuente con la calificación correspondiente de las Comunidades Autónomas y Ciudades de Ceuta y Melilla, por cumplir los requisitos de uso, destino, calidad, precio máximo establecido (tanto para venta como para alquiler) y, en su caso, superficie y diseño, así como cualesquiera otros establecidos en la normativa correspondiente", determinándose a continuación una serie de requisitos mínimos que habrán de cumplir en todo caso.
} 


\section{CONTENIDO DEL DECRETO-LEY 6/2013, DE 9 DE ABRIL}

\section{Consideraciones previas sobre el uso del Decreto-Ley.}

La Constitución española (CE) regula en el art. 86 el Decreto-Ley como uno de los dos supuestos en los que el Gobierno puede dictar una norma con rango de ley.

Esta figura se caracteriza, además de por constituir una facultad propia del Ejecutivo, por las siguientes tres notas: la primera, por la existencia de un presupuesto habilitante consistente en una situación de "extraordinaria y urgente necesidad"; la segunda, por no poder afectar su regulación a las materias citadas en el art. 86.1 CE (al ordenamiento de las instituciones básicas del Estado; los derechos, deberes y libertades de los ciudadanos regulados en el Título I de la Constitución; al régimen de las Comunidades Autónomas; y al Derecho electoral general ${ }^{3}$; y la tercera, por tratarse de una norma de carácter provisional.

La Ley Orgánica 2/2007, de 19 de marzo, de reforma del Estatuto de Autonomía para Andalucía (EAA), introduce en su art. 110 la figura del DecretoLey en el ordenamiento jurídico andaluz de forma que, en caso de extraordinaria y urgente necesidad, el Consejo de Gobierno tenga la facultad de dictar este tipo de medidas legislativas provisionales, las cuales no podrán afectar a los derechos establecidos en este Estatuto, al régimen electoral, ni a las instituciones de la Junta de Andalucía. Dado su carácter provisional, estas normas quedarán derogadas si en el plazo improrrogable de treinta días subsiguientes a su promulgación no se convalidan expresamente por el Parlamento andaluz tras un debate y votación de totalidad. Durante el referido plazo, el Parlamento podrá acordar la tramitación de los Decretos-Leyes como Proyectos de Ley por el procedimiento de urgencia.

Desde que se incorporase esta figura al Derecho propio de la Comunidad Autónoma de Andalucía, el Ejecutivo andaluz ha hecho un constante uso del mismo para abordar situaciones tan dispares como: la convalidación de determinados actos de la Agencia Tributaria de Andalucía dictados durante la vi-

\footnotetext{
${ }^{3}$ Asimismo, el Decreto-Ley no puede entrar a regular materias reservadas a Ley Orgánica, aquellas que la Constitución expresamente exige que sean aprobadas por Ley de las Cortes Generales y también se prohíbe la delegación legislativa por Decreto-Ley.
} 
gencia del Decreto 324/2009, de 8 de septiembre, por el que se aprobaba su Estatuto, en cuanto adolezcan de cualquier vicio administrativo dimanante de la nulidad del mentado Decreto; la reordenación del sector público andaluz; o la regularización de la situación de los interinos acogidos al pacto de estabilidad que se habían visto afectados por el último concurso de méritos. Me pregunto si se habrían evitado recursos y discordancias normativas y logrado un mayor consenso si en tales casos, por ejemplo, se hubiera tramitado y debatido ante el Parlamento un Proyecto de Ley de Reordenación del Sector Público, se hubiera hecho uso de la posibilidad que ofrece la Disposición Transitoria Cuarta de la Ley 7/2007, de 12 de abril, del Estatuto del Empleado Público para consolidar a tales interinos dentro de la función pública andaluza o, mejor, se hubiese aprovechado tal oportunidad para tramitar un Proyecto de Ley de modificación de la Ley de Ordenación de la Función Pública de Andalucía adecuado a la citada legislación básica.

En concreto, el balance normativo de estos últimos años en la Comunidad Autónoma ha sido el siguiente: en 2008, frente a tres Leyes, se aprobaron dos Decretos-Leyes ${ }^{4}$; en 2009, se aprobaron cinco Leyes y tres Decretos-Leyes ${ }^{5}$; en 2010, se aprobaron doce Leyes y siete Decretos-Leyes ${ }^{6}$; en 2011 , se aprobaron once Leyes y tres Decretos-Leyes ${ }^{7}$; en 2012 se aprobaron seis Leyes y cinco De-

\footnotetext{
${ }^{4}$ Decreto-Ley 1/2008, de 3 de junio, de medidas tributarias y financieras de impulso a la actividad económica de Andalucía y el Decreto-Ley 2/2008, de 9 de diciembre, por el que se aprueba el Programa de Transición al Empleo de la Junta de Andalucía (PROTEJA).

${ }^{6}$ El Decreto-Ley 1/2010, de 9 de marzo, de medidas tributarias de reactivación económica de la Comunidad Autónoma de Andalucía; el Decreto-Ley 2/2010, de 28 de mayo, por el que se aprueban medidas urgentes en materia de retribuciones en el ámbito del sector público andaluz; el Decreto-Ley 3/2010, de 8 de junio, por el que se modifica, amplía y aprueba una nueva edición del Programa de Transición al Empleo de la Junta de Andalucía (PROTEJA); el Decreto-Ley 4/2010, de 6 de julio, de medidas fiscales para la reducción del déficit público y para la sostenibilidad; el Decreto-Ley 5/2010, de 27 de julio, por el que se aprueban medidas urgentes en materia de reordenación del sector público; el Decreto-Ley 6/2010, de 23 de noviembre, de medidas complementarias del Decreto-Ley 5/2010, de 27 de julio, por el que se aprueban medidas urgentes en materia de reordenación del sector público; y el Decreto-Ley 7/2010, de 28 de diciembre, de medidas para potenciar inversiones empresariales de interés estratégico para Andalucía y de simplificación, agilización administrativa y mejora de la regulación de actividades económicas en la Comunidad Autónoma de Andalucía.

${ }^{7}$ El Decreto-Ley 1/2011, de 26 de abril, por el que se modifica la Ley 15/1999, de 16 de diciembre, de Cajas de Ahorros de Andalucía; el Decreto-Ley 2/2011, de 25 de octubre, por el que se eleva el mínimo exento para personas con discapacidad y se regula el tipo de gravamen del Impuesto sobre el Patrimonio en la Comunidad Autónoma de Andalucía; y el Decreto-Ley 3/2011, de 13 de diciembre, por el que se aprueban medidas urgentes sobre prestación farmacéutica del Sistema Sanitario Público de Andalucía.
} 
cretos-Leyes $^{8}$; y a fecha de mediados de julio de 2013, frente a las dos Leyes aprobadas, relativas a la creación de dos colegios profesionales, se han aprobado ya ocho Decretos-Leyes ${ }^{9}$.

El antepenúltimo de estos Decretos-Leyes, el 6/2013, de 9 de abril ${ }^{10}$, se ha dictado, según se fundamenta en su Exposición de Motivos, para dar respuesta a la situación de extremada y urgente necesidad que padece un sector de la población que se ve desahuciada de su vivienda y que necesita un techo bajo el que vivir.

De acuerdo con lo dispuesto en el art. 27.2.b) de la Ley Orgánica 2/1979, de 3 de octubre, el control sobre la constitucionalidad de un Decreto-Ley compete al Tribunal Constitucional (TC).

En este contexto, el TC ha reconocido que la determinación de cuándo la

${ }^{8}$ El Decreto-Ley 1/2012, de 19 de junio, de medidas fiscales, administrativas, laborales y en materia de Hacienda Pública para el reequilibrio económico-financiero de la Junta de Andalucía; el Decreto-Ley 2/2012, de 19 de junio, por el que se modifica la Ley 9/2007, de 22 de octubre, de la Administración de la Junta de Andalucía, en determinados aspectos de la organización territorial; el Decreto-Ley 3/2012, de 24 de julio, por el que se modifica el Decreto-Ley 1/2012, de 19 de junio, de medidas fiscales, administrativas, laborales y en materia de Hacienda Pública para el reequilibrio económico-financiero de la Junta de Andalucía, para adaptarlo al Real Decreto-ley 20/2012, de 13 de julio, de Medidas para garantiza la estabilidad presupuestaria y de fomento de la competitividad; el Decreto-Ley 4/2012, de 16 de octubre, de medidas extraordinarias y urgentes en materia de protección sociolaboral a ex-trabajadores y ex-trabajadoras andaluces afectados por procesos de reestructuración de empresas y sectores en crisis; el Decreto-Ley $5 / 2012$, de 27 de noviembre, de medidas urgentes en materia urbanística y para la protección del litoral de Andalucía.

${ }^{9}$ El Decreto-Ley 1/2013, de 29 de enero, por el que se modifica el Decreto Legislativo 1/2012, de 20 de marzo, por el que se aprueba el Texto Refundido de la Ley del Comercio Interior de Andalucía y se establecen otras medidas urgentes en el ámbito comercial, turístico y urbanístico; el Decreto-Ley 2/2013, de 12 de marzo, por el que se confirman determinados actos de la Agencia Tributaria de Andalucía; el Decreto-Ley 3/2013, de 19 de marzo, por el que se modifica la Ley 18/2007, de 17 de diciembre, de la Radio y Televisión de titularidad autonómica gestionada por la Agencia Pública Empresarial de la Radio y Televisión de Andalucía (RTVA); el Decreto-Ley 4/2013, de 2 de abril, por el que se modifica la Ley 4/2002, de 16 de diciembre, de creación del Servicio Andaluz de Empleo; el Decreto-Ley $5 / 2013$, de 2 de abril, por el que se adoptan determinadas medidas sobre el empleo del personal funcionario interino en la Administración General de la Junta de Andalucía, para el mantenimiento de la calidad y eficiencia de los servicios públicos a la ciudadanía; el Decreto-Ley 6/2013, de 9 de abril, objeto de las reflexiones de este trabajo; el Decreto-Ley 7/2013, de 30 de abril, de medidas extraordinarias y urgentes para la lucha contra la exclusión social en Andalucía; y el Decreto-Ley 8/2013, de 28 de mayo, de Medidas de Creación de Empleo y Fomento del Emprendimiento.

10 Convalidado por el Pleno del Parlamento de Andalucía, en sesión celebrada el día 8 de mayo de 2013, vid. la publicación del acuerdo de convalidación en el BOJA núm. 96, de 20 de mayo de 2013. 
situación puede calificarse de "extraordinaria y urgente necesidad" constituye un "juicio puramente político" que compete al Gobierno, al que incumbe la dirección política del Estado, sin perjuicio de que el Tribunal Constitucional pueda entrar a controlar los "supuestos de uso abusivo o arbitrario" (STC 29/1982, de 31 de mayo) que pudieran desvirtuar la potestad legislativa ordinaria de las Cortes Generales, las cuales pueden legislar también por el procedimiento de urgencia ${ }^{11}$.

Desde su Sentencia 29/1982, de 31 de mayo ${ }^{12}$, el TC ha intentado ir fijando criterios que ayuden a delimitar los contornos del concepto jurídico indeterminado al que se alude con la expresión de situación de "extraordinaria y urgente necesidad". Ha sostenido que para controlar la concurrencia de ese presupuesto habilitante es preciso analizar dos elementos: "en primer lugar, los motivos que habiendo sido tenidos en cuenta por el Gobierno en su aprobación, hayan sido explicitados de una forma razonada; y, en segundo lugar, la existencia de una necesaria conexión entre la situación de urgencia definida y la medida concreta adoptada para subvenir a la misma".

11 Precisamente, en el plano parlamentario andaluz, el pasado 15 de noviembre, el PSOE e IU rechazaron la moción del PP 9-12/M-000006, relativa a política general en materia de vivienda, en la que se pedía que la Junta de Andalucía impulsara la puesta a disposición de su parque de vivienda social y de promoción pública para las familias más necesitadas y perjudicadas por la crisis (Vid. el Diario de Sesiones del Parlamento de Andalucía Plenos 19, de 15 de noviembre de 2012, págs. 9-15 y el Boletín Oficial del Parlamento de Andalucía núm. 113, de 27 de noviembre de 2012, pág. 15).

La propuesta realizada por el PP de cesión de viviendas propiedad de la Junta de Andalucía a personas desahuciadas se había elevado a la vista de la información contenida en la página web de la Empresa Pública de Suelo de Andalucía (EPSA), que reconocía la existencia de unas 5.000 viviendas de titularidad pública que se encontrarían vacías en Andalucía, de un parque total de unas 81.000 , destinadas a venta y alquiler.

En esta línea, el Informe anual del Defensor del Pueblo correspondiente a la gestión realizada por esta Institución durante el ejercicio 2012 recoge, entre otras observaciones, la advertencia que el Defensor realizó a la Consejería de Fomento y Vivienda en julio de 2012 sobre la existencia de "miles de viviendas sometidas a algún régimen de protección pública u oficial desocupadas" en Andalucía, al tiempo que recoge varias quejas de oficio, entre ellas una dirigida a la Empresa Pública de Suelo en Andalucía sobre la posible existencia de viviendas desocupadas en Úbeda (Jaén) desde 2006 (Vid. BOPA núm. 200, de 13 de abril de 2013, págs. 27, 60-67, 91-98 y 221).

Desde diciembre de 2012, sin embargo, no es posible consultar la oferta de vivienda protegida en la web de EPSA, ya que se indica que "la información que aparece en esta sección es una recopilación histórica de la gestión de EPSA en materia de promoción de vivienda protegida, no actualizada dado que esta empresa está construyendo una nueva página web que estará plenamente activa en breve, y en la que aparecerá toda la información de interés puesta al día”.

Esperemos que cuando se apruebe la Ley de Transparencia se pueda acceder a dicha información.

${ }^{12}$ Asimismo, vid. SSTC 6/1983, de 4 de febrero, 182/1997, de 28 de octubre, 137/2003, de 3 de julio y 189/2005, de 7 de julio. 
Merece la pena subrayar el dato de que sólo en contadas ocasiones el Tribunal Constitucional ha declarado la inconstitucionalidad de un Decreto-Ley por falta del presupuesto habilitante, al entender que no concurría una situación de extraordinaria y urgente necesidad ${ }^{13}$.

No obstante, al margen del posible control sobre la constitucionalidad del presupuesto habilitante del Decreto-Ley 6/2013, esta norma ha adoptado, en aras del interés social, una serie de medidas, la más polémica y discutible, la regulación de la expropiación temporal del uso de viviendas a las entidades financieras y sus filiales inmobiliarias o entidades de gestión de activo que, por afectar directamente al derecho a la propiedad privada, podría fundamentar, asimismo, la interposición de un recurso de inconstitucionalidad contra el mismo.

\section{Sobre la suficiencia de las competencias que avalan el Decre- to-Ley $6 / 2013$.}

Tal y como explicita la Exposición de Motivos del Decreto-Ley 6/2013, éste se dicta al amparo del título competencial recogido en el art. 56 del Estatuto de Autonomía para Andalucía, que establece la competencia exclusiva de esta Comunidad Autónoma en materia de vivienda, urbanismo y ordenación del territorio, respetándose las competencias reservadas al Estado en el art. 149.1.1 y $18^{\mathrm{a}}$ de la Constitución.

No se hace, en cambio, una cita expresa a cuál es la competencia que avala a la Comunidad Autónoma de Andalucía para dictar una norma en la que se regula la controvertida expropiación temporal de viviendas desocupadas en manos de los bancos y sus filiales inmobiliarias.

Pues bien, de conformidad con lo dispuesto en el art. 47.3 EAA, corresponde a la Comunidad Autónoma en materia de expropiación forzosa la "competencia ejecutiva" 14 que incluye, en todo caso: determinar los supuestos, las causas y las condiciones en que las Administraciones andaluzas pueden

13 Vid. SSTC 68/2007, de 28 de marzo, con relación al Real Decreto-ley 5/2002, de 24 de mayo, de medidas urgentes para la reforma del sistema de protección por desempleo y mejora de la ocupabilidad y la STC 137/2011, de 14 de septiembre, con relación al Real Decreto-Ley 4/2000, de 23 de junio, de medidas urgentes de liberalización en el sector inmobiliario y transportes.

${ }^{14}$ De acuerdo con el art. 42 EAA, las competencias que corresponden a la Comunidad Autónoma de Andalucía se clasifican en: exclusivas; compartidas; ejecutivas; y competencias relacionadas con la aplicación del Derecho Comunitario, que comprenden el desarrollo y la ejecución de la normativa de la Unión Europea cuando afecte al ámbito de las competencias de la Comunidad Autónoma. 
ejercer la potestad expropiatoria; establecer criterios de valoración de los bienes expropiados según la naturaleza y la función social que tengan que cumplir, de acuerdo con la legislación estatal; y crear y regular un órgano propio para la determinación del justiprecio y fijar su procedimiento.

De acuerdo con el tenor del citado precepto estatutario, la competencia "ejecutiva" 15 de la Comunidad Autónoma para establecer la función social que tengan que cumplir los bienes expropiados ha de realizarse "de acuerdo con la legislación estatal", esto es, fundamentalmente de acuerdo con la Ley de Expropiación Forzosa de 16 de diciembre de 1954, la cual regula en sus artículos 71-75 la expropiación por incumplimiento de la función social de la propiedad y establece el procedimiento que ha de seguirse.

En este contexto, hay que traer a colación los pronunciamientos de diversas sentencias del Tribunal Constitucional en las que ha abordado el tema de si las Comunidades Autónomas ostentan competencias normativas en materia de expropiación, o ésta corresponde en su integridad al Estado, con base en el art. 149.1.18 CE, así: la STC 37/1987, de 26 de marzo, por la que resuelve el recurso de inconstitucionalidad contra la Ley del Parlamento de Andalucía 8/1984, de 3 de julio, de Reforma Agraria (FJ 6º); la STG 186/1993, de 7 de junio, por la que se resuelve un recurso de inconstitucionalidad contra diversos preceptos de la Ley de la Asamblea de Extremadura 1/1986, de 2 de mayo, de regulación de las Dehesas (FJ 2 ${ }^{\circ}$; y la STC 17/1990, de 7 de febrero, por la que se resuelve un recurso de inconstitucionalidad contra diversos preceptos de la Ley del Parlamento de Canarias 10/1987, de 5 de mayo, de Aguas (FJ 10%).

En las citadas Sentencias el TC reconoce que "la reserva constitucional en favor del Estado sobre la legislación de expropiación forzosa no excluye que por Ley autonómica puedan establecerse, en el ámbito de sus propias competencias, los casos o supuestos en que procede aplicar la expropiación forzosa, determinando las causas de expropiar o los fines de interés público a que aquélla debe servir. De lo contrario se llegaría al absurdo de que las Comunidades

Las competencias ejecutivas comprenden la función ejecutiva que incluye la potestad de organización de su propia Administración y, en general, aquellas funciones y actividades que el ordenamiento atribuye a la Administración Pública y, cuando proceda, la aprobación de disposiciones reglamentarias para la ejecución de la normativa del Estado.

${ }^{15}$ Vid. la interpretación que realiza el TG del concepto de competencia ejecutiva para salvar la constitucionalidad de los términos en los que se expresa el art. 112 de la Ley Orgánica 6/2006, de 19 de julio, de reforma del Estatuto de Autonomía de Cataluña, en el FJ 61 de la STC 31/2010, de 28 de junio, así como el voto particular que formula el Magistrado don Vicente Conde Martín de Hijas. 
Autónomas, habiendo constatado la existencia de nuevas causas de utilidad pública o interés social justificadoras de la expropiación para el desarrollo de sus respectivas competencias, tuvieran que solicitar del Estado la regulación formal de aquéllas, o a la no menos absurda conclusión, por petrificadora del ordenamiento, de no poder identificar tales supuestos legitimadores más allá de los que, antes de la instauración del Estado de las Autonomías hayan sido declarados como tales por las Leyes del Estado en materias sobre las que éste ha dejado de tener competencia".

A la vista de estos pronunciamientos se puede sostener que la Comunidad Autónoma andaluza tiene, en materia de vivienda, competencia para regular este supuesto de expropiación temporal del uso de viviendas a los bancos y sus filiales inmobiliarias con base en la salvaguarda del interés social.

No obstante, no hay que olvidar que, por otra parte, la Constitución atribuye al Estado la competencia para regular las condiciones básicas que garanticen la igualdad de todos los españoles en el ejercicio de los derechos constitucionales y la competencia sobre legislación mercantil y procesal, legislación civil, para dictar las bases de la ordenación del crédito, banca y seguros, las bases y coordinación de la planificación general de la actividad económica y la competencia en legislación sobre expropiación forzosa (art. 149.1.1 ${ }^{\mathrm{a}}, 6^{\mathrm{a}}, 8^{\mathrm{a}}$, $11^{\mathrm{a}}, 13^{\mathrm{a}}$ y $\left.18^{\mathrm{a}} \mathrm{CE}\right)$.

Atendiendo a dichos títulos competenciales, y so pena de crear una situación de inseguridad jurídica y de desigualdad entre los españoles que residan en una Comunidad Autónoma u otra, entendemos que sería más acertado abordar esta cuestión de suma relevancia e interés, tanto jurídico como social, a través de una regulación legal a nivel estatal que configure el contenido esencial del derecho de propiedad de la vivienda, establezca cuáles sean sus limitaciones, delimite su función social y las consecuencias que conlleve su incumplimiento $^{16}$.

${ }^{16}$ Desde que se publicara el Decreto Ley 6/2013 y se escribiera en abril este artículo han sido varias las normas que se han ido publicando a nivel estatal y autonómico sobre esta materia y que hemos ido incorporando. Asimismo, durante este tiempo, hay que subrayar que el 9 de julio se interpuso un recurso de inconstitucionalidad, promovido por el Presidente del Gobierno, contra el art. 1 y la DA $2^{\mathrm{a}}$ del Decreto Ley 6/2013, fundamentado en que: la norma andaluza afecta al contenido esencial del derecho a la propiedad de la vivienda, que es una materia cuya regulación está reservada a las Cortes Generales; que establece una responsabilidad sancionadora al margen del principio de culpabilidad que exige la Constitución; y por establecer una regulación contraria al principio de igualdad. Finalmente el recurso de incons- 


\section{Principales medidas adoptadas.}

Las medidas que contempla el Decreto-Ley 6/2013 para paliar fundamentalmente el problema de los desahucios de viviendas en Andalucía implican una serie modificaciones normativas. El primer grupo de éstas afectan a la Ley 1/2010, de 8 de marzo, Reguladora del Derecho a la Vivienda en Andalucía (LDVA) y a la Ley 13/2005, de 11 de noviembre, de Medidas para la Vivienda Protegida y el Suelo (LMVPS). El segundo, a la Ley 8/1997, de 23 de diciembre, por la que se aprueban medidas en materia tributaria, presupuestaria, de empresas de la Junta de Andalucía y otras entidades, de recaudación, de contratación, de función pública y de fianzas de arrendamientos y suministros. Y el tercero, a la Ley 9/2001, de 12 de julio, por la que se establece el sentido del silencio administrativo y los plazos de determinados procedimientos como garantías procedimentales para los ciudadanos.

Centrándonos en las medidas que afectan al primer grupo, destacamos las siguientes:

a) La expropiación temporal del uso de viviendas.

Con el argumento de que toda persona tiene "derecho a una vivienda" y que los poderes públicos tienen el deber de "promover las condiciones necesarias y establecer las normas pertinentes para hacer efectivo este derecho", según se establece en la Declaración Universal de Derechos Humanos, el Pacto Internacional de Derechos Económicos, Sociales y Culturales, la Constitución Española, el Estatuto de Autonomía de Andalucía y la Ley del Derecho a la Vivienda en Andalucía, el Decreto-Ley 6/2013 introduce una novedosa limitación del derecho de propiedad en nuestro ordenamiento consistente en una expropiación temporal del uso de las viviendas a los bancos y sus filiales inmobiliarias.

Se defiende que, hasta el momento, no se ha tenido en cuenta la "la perspectiva social que necesariamente tiene la vivienda", que, en la práctica, "es considerada un simple bien de consumo sujeto a las leyes del mercado" y es, por esta razón que, a través de esta medida, se pretende asegurar la "función social" de la vivienda.

titucionalidad $\mathrm{n}^{\circ}$ 4286-2013 ha sido admitido a trámite por el TC que, asimismo, ha acordado la suspensión de la vigencia y aplicación de los preceptos impugnados (vid. BOE núm. 166, de 12 de julio de 2013 y BOJA núm. 142, de 22 de julio de 2013). 
Concretamente, es la Disposición Adicional Segunda del Decreto-Ley 6/2013 la que regula la declaración de interés social de la cobertura de necesidad de vivienda de las personas en especiales circunstancias de emergencia social incursas en procedimientos de desahucio por ejecución hipotecaria, a efectos de expropiación forzosa del uso de la vivienda.

El plazo máximo establecido para tal expropiación es de tres años, a contar desde la fecha del lanzamiento acordado por el órgano jurisdiccional competente.

El ámbito de aplicación de esta normativa abarca a las viviendas incursas en procedimientos de desahucio instado por entidades financieras, o sus filiales inmobiliarias o entidades de gestión de activos, en los cuales resulte adjudicatario del remate alguna de ellas, sin perjuicio de lo dispuesto en la normativa básica estatal $^{17}$.

Temporalmente, esta medida será aplicable a los procesos judiciales o extrajudiciales de ejecución hipotecaria que se hubieran iniciado antes de la entrada en vigor de este Decreto-Ley, esto es, antes del 12 de abril de 2013, en los que no se hubiese ejecutado el lanzamiento o se hubiese producido el lanzamiento después de la entrada en vigor del mismo pero la vivienda esté desocupada.

El procedimiento regulado en esta Disposición se inicia a solicitud del interesado.

Para poder ser beneficiario de esta expropiación, la persona solicitante habrá de cumplir con una serie requisitos, así:

$\left.1^{\circ}\right)$ Tener su residencia habitual y permanente en la vivienda objeto de ejecución hipotecaria, siendo su única vivienda en propiedad y no poseer ningún miembro de la unidad familiar que conviva en la vivienda objeto de ejecución hipotecaria la titularidad de ninguna vivienda.

${ }^{17}$ No obstante ser esta medida únicamente aplicable a los bancos, en el plano local se ha adoptado, con base en el argumento de la función social de la vivienda del Decreto-Ley 6/2013, una iniciativa por parte del Ayuntamiento onubense de San Juan del Puerto consistente en iniciar la expropiación de cuatro viviendas vacías titularidad de la Junta de Andalucía sitas en el municipio y su puesta a disposición de varias familias sanjuaneras en riesgo de exclusión social, tras el rechazo de los varios requerimientos previos que para ello había realizado el Consistorio a la Junta de Andalucía. 
Parece, pues, que la norma no contempla la posibilidad de que el solicitante o algún otro miembro de la unidad familiar pueda tener algún otro derecho real de uso o disfrute sobre alguna otra vivienda (derecho de usufructo, uso o habitación).

$2^{\circ}$ Tener la condición inicial de propietarios y deudores hipotecarios.

$3^{\circ}$ ) Que el lanzamiento pueda generar una situación de emergencia o exclusión social.

$\left.4^{\circ}\right)$ Y, por último, cumplir una serie de requisitos de carácter económico (que el procedimiento de ejecución hipotecaria sea consecuencia del impago de un préstamo concedido para poder hacer efectivo el derecho a la vivienda por la persona; que las condiciones económicas de ésta hayan sufrido un importante menoscabo, provocando una situación de endeudamiento sobrevenido respecto a las condiciones y circunstancias existentes cuando se concedió el préstamo hipotecario; y que el conjunto de ingresos de la unidad familiar no supere 3 veces el Indicador Público de Renta de Efectos Múltiples ${ }^{18}$ ).

Por consiguiente, para el inicio del procedimiento de expropiación forzosa, la persona interesada deberá aportar, además de la solicitud dirigida al efecto y de la documentación acreditativa del proceso de ejecución hipotecaria en el que su vivienda se encuentre incursa, la documentación acreditativa de: su situación económica (certificado de rentas, últimas tres nóminas percibidas, certificado expedido por la entidad gestora de las prestaciones en el que figure la cuantía mensual percibida en concepto de prestaciones o subsidios por desempleo, etc.); los ingresos de los miembros de la unidad familiar; del número de personas que habitan la vivienda (libro de familia, certificado de empadronamiento, etc.); titularidad de los bienes (certificados de titularidades expedidos por el Registro de la Propiedad en relación con cada uno de los miembros de la unidad familiar, escrituras de compraventa de la vivienda y de constitución de la garantía hipotecaria...); declaración responsable de la persona deudora o deudoras relativa al cumplimiento de los requisitos exigidos por este DecretoLey; e informe de los Servicios Sociales Comunitarios del municipio sobre la situación de emergencia o exclusión social en que puede quedar el beneficiario en caso de lanzamiento.

\footnotetext{
18 De acuerdo con lo dispuesto en la DA 82 ${ }^{\mathrm{a}}$ de la Ley 17/2012, de 27 de diciembre, de Presupuestos Generales del Estado para 2013, las cuantías del Indicador Público de Renta de Efectos Múltiples están fijada para este año en: 17,75 euros (diario); 532,51 euros (mensual); 7.455,14 euros o 6.390,13 euros (anual, dependiendo de si expresamente se excluyen o no las pagas extras).
} 
La resolución que acuerde el inicio del procedimiento expropiatorio habrá de comunicarse al órgano judicial que esté conociendo del correspondiente procedimiento de ejecución hipotecaria.

En cuanto a la determinación del órgano competente para resolver estos procedimientos, la norma distingue según afecte a una vivienda o a más. En el primer supuesto, será competente para su resolución el titular de la Delegación Territorial en materia de vivienda. Si la afectación alcanza a una generalidad de situaciones, corresponderá a la persona titular de la Dirección General competente en materia de vivienda.

El procedimiento de expropiación temporal del uso de la vivienda deberá respetar el establecido en la legislación de expropiación forzosa y, en su caso, en la legislación sectorial aplicable.

Mediante Decreto del Consejo de Gobierno se declarará, previa información pública y motivadamente, el interés social y la necesidad de ocupación a efectos de expropiación forzosa temporal del uso de viviendas, pudiendo ser dicha competencia objeto de delegación en la Consejería competente en materia de vivienda, en la actualidad, la Consejería de Fomento y Vivienda.

A los efectos previstos en el artículo 52 de la Ley de Expropiación Forzosa, de 16 de diciembre de 1954, se declara "urgente" la ocupación prevista en este Decreto-Ley.

Destaca el reconocimiento de un derecho de reversión en el caso de que las circunstancias de la persona beneficiaria se modificaran antes de transcurrir los referidos tres años o cuando se pierda la condición de beneficiario.

Asimismo, debe subrayarse que la persona beneficiaria quedará obligada al pago a la Administración expropiante de una cantidad en concepto de contribución al pago de justiprecio, en cuantía no superior al 25\% de los ingresos de la unidad familiar que conviva en la misma, ni superior a la cuantía del justiprecio.

Y, por último, siendo conscientes de las posibilidades económicas, se dice que, en todo caso, lo establecido en esta Disposición estará en función de las disponibilidades presupuestarias. 
b) La potestad sancionadora.

Entre las modificaciones introducidas en el texto de la Ley 1/2010, de 8 de marzo, Reguladora del Derecho a la Vivienda en Andalucía destaca la inclusión en su artículo 1 de un apartado quinto en el que se ensalza, como garantía legal del efectivo cumplimiento del derecho a una vivienda digna y adecuada, el ejercicio de las potestades de inspección y sanción de las infracciones tipificadas en materia de vivienda, siendo competente para ejercitar las correspondientes potestades de declaración, inspección y sanción, por lo que se refiere a vivienda deshabitadas, la Consejería con competencia en materia de vivienda.

En concordancia con ello, se ha modificado el art. 4 LDVA, regulador del contenido de las actuaciones de las Administraciones Públicas andaluzas para garantizar el efectivo disfrute del derecho a una vivienda digna, incluyendo el ejercicio de las potestades de inspección administrativa y sancionadora en materia vivienda y las actuaciones de fomento para evitar la existencia de viviendas deshabitadas [letras e) y f)].

Concretamente, dentro del nuevo Título VII de la LDVA, el Capítulo II se dedica a la potestad sancionadora en materia de vivienda. Recordemos que, hasta el momento, las únicas infracciones y sanciones tipificadas en materia de vivienda eran las contempladas en la Ley 13/2005 para las viviendas protegidas.

De acuerdo con lo dispuesto en el art. 52 LDVA, se consideran infracciones en materia de vivienda a todas las acciones u omisiones tipificadas como tales por la presente Ley, sin perjuicio de las especificaciones que puedan efectuarse por reglamento, dentro de los límites establecidos por la legislación vigente en materia sancionadora.

$\mathrm{El}$ art. 53 LDVA establece una clasificación tripartita de las infracciones en: muy graves ${ }^{19}$, graves ${ }^{20}$ y leves ${ }^{21}$.

${ }^{19}$ Art. 53.1. Son infracciones muy graves:

“a) No dar efectiva habitación a la vivienda en los términos establecidos en el artículo 25, siempre que el titular de la misma sea una persona jurídica, bien en régimen de pleno dominio, bien como titular de una participación mayoritaria en un condominio sobre la misma. Igual determinación rige para las sociedades irregulares.

b) Arrendar, transmitir o ceder el uso de inmuebles para su destino a vivienda sin cumplir las condiciones de seguridad según lo dispuesto en el artículo 3 de esta Ley y demás normativa aplicable.

c) Incumplir el deber de conservación y rehabilitación previsto en el artículo 17.2 de esta Ley si su- 
A diferencia del régimen descrito anteriormente para la expropiación temporal del uso de viviendas, en materia sancionadora sí pueden ser sancionados como sujetos responsables las personas físicas (excepto en el caso de tener la vivienda deshabitada), además de las personas jurídicas, las herencias yacentes, comunidades de bienes y demás entidades que, carentes de personalidad jurídica, constituyan una unidad económica o un patrimonio separado.

La Ley contempla una serie de supuestos excluyentes de tal responsabilidad, por ejemplo, cuando concurra fuerza mayor (concepto jurídico indeterminado que debiera haberse concretado a modo, por ejemplo, como hace el art. 231 del Real Decreto Legislativo 3/2011, de 14 de noviembre, por el que se aprueba el Texto Refundido la Ley de Contratos del Sector Público); cuando deriven de una decisión colectiva, para quienes hubieran salvado su voto o

pone un riesgo para la seguridad de las personas o un incumplimiento de un programa previo de rehabilitación forzosa, de acuerdo con lo señalado en los artículos 18 y 19.

d) La inexactitud en los documentos o certificaciones que sean necesarios para obtener una resolución administrativa con reconocimiento de derechos económicos, de protección o de habitabilidad, con el fin de obtener un acto favorable a los infractores o a terceros, de eludir una orden de ejecución u otro acto no favorable a las personas interesadas o bien para la obtención de medidas de fomento en los términos de los artículos 9, 17, 18, 19 y 42 y siguientes."

${ }^{20}$ Art. 53.2. Son infracciones graves:

“a) Arrendar, transmitir o ceder el uso de inmuebles para su destino a vivienda incumpliendo condiciones de habitabilidad según lo dispuesto en el artículo 3 de esta Ley y demás normativa aplicable.

b) Incumplir el deber de conservación y rehabilitación previsto en el artículo 17.2 de esta Ley si supone una afectación grave de las condiciones de habitabilidad de los edificios.

c) La reiteración, una vez advertida la infracción, ante la negativa a suministrar datos a la Administración o ante la obstrucción a las funciones de información, control o inspección, conforme se dispone en los artículos 27, 28, 29 y 30. A estos efectos, se entiende igualmente por obstrucción la remisión de información o la aportación de datos o documentos de forma inexacta si ello incide en el ejercicio de las potestades de inspección o en la constatación, calificación o graduación de la infracción.

d) El incumplimiento de los deberes que se establecen para las Agencias de Fomento del Alquiler en la presente Ley y en los artículos 10 y siguientes del Decreto 33/2005, de 15 de febrero, por el que se regulan las citadas entidades, o norma que lo sustituya.

e) No comunicar a la Administración competente la concurrencia de hechos sobrevenidos que supongan una modificación de la situación económica o circunstancias de otra índole que hayan sido tenidas en cuenta para ser beneficiaria de las medidas de fomento reguladas en los artículos 9 y 42 y siguientes."

${ }^{21}$ Art. 53.3. Son infracciones leves:

"a) Incumplir el deber de conservación y rehabilitación, si supone una afectación leve de las condiciones de habitabilidad de los edificios según se previene en el artículo 3.

b) Negarse a suministrar datos a la Administración u obstruir o no facilitar las funciones de información, control o inspección, conforme a lo dispuesto en los artículos 27, 28, 29 y 30 de esta Ley. A estos efectos, se entiende por obstrucción, igualmente, la remisión de información o la aportación de datos o documentos de forma inexacta, o con incumplimiento de plazos, si ello incide en el ejercicio de las potestades de inspección o en la constatación, calificación o graduación de la infracción." 
no hubieran asistido a la reunión en que se adoptó la misma (supuesto este último que podría fomentar el absentismo como forma de salvar la responsabilidad); y cuando se realicen por quienes carezcan de capacidad de obrar, sin perjuicio de la obligación de restauración o indemnización que, en su caso, haya de exigirse a su representante legal, a resultas de la comisión de la infracción.

En el caso de que la infracción se impute a una persona jurídica, podrán ser consideradas responsables las personas que ejerzan la administración de hecho o de derecho y las personas físicas que integran los correspondientes organismos rectores o de dirección, de acuerdo con lo establecido en el correspondiente régimen jurídico. En todo caso, las personas jurídicas serán responsables de las infracciones administrativas cometidas en nombre o por cuenta de las mismas, y en su provecho, por sus representantes legales y las personas que ejerzan la administración de hecho o de derecho.

A continuación se contemplan determinados supuestos de responsabilidad solidaria (por la concurrencia de varios sujetos infractores, en caso de partícipes o cotitulares de herencias yacentes, comunidades de bienes, etc.) y de responsabilidad subsidiaria.

En cuanto a las medidas aplicables ante la comisión de una infracción, la Ley dispone, por una parte, medidas de reconducción de conductas, consistentes en multas coercitivas y, por otra parte, medidas sancionadoras, consistentes fundamentalmente en la imposición de multas.

En cuanto a la regulación de las multas coercitivas, el art. 59 LDVA establece que la Administración competente tiene la facultad discrecional de hacer uso de este medio de ejecución forzosa, imponiéndolas de forma reiterada y consecutiva, hasta un máximo de tres, cuando transcurran los plazos señalados para llevar a cabo una acción u omisión u obligación de hacer o de no hacer previamente requerida. La cuantía de cada una de las multas no debe superar, para la primera multa coercitiva, el 20 por ciento de la multa sancionadora establecida para el tipo de infracción cometida, el 30 por ciento, para la segunda multa coercitiva y el 40 por ciento, para la tercera multa coercitiva, y en todas ellas por una cuantía mínima de 1.000 euros.

Respecto al contenido del precepto comentado, consideramos que, con base en la cobertura legal específica que requiere la multa coercitiva, de acuerdo con el tenor del art. 99.1 de la Ley 30/1992, de 26 de noviembre, de Régimen Jurídico de las Administraciones Públicas y del Procedimiento Administrativo Común, debiera haberse previsto no sólo su cuantía, sino también el lapsus 
temporal que ha de mediar entre una y otra, que ha de ser suficiente y adecuado para que el sujeto cumpla con la obligación previamente requerida.

Asimismo, la Ley explicita unos criterios (atenuantes o agravantes) que habrán de tenerse en cuenta por la Administración a la hora de graduar la sanción in melius o in peius.

Las sanciones de tipo económico, reguladas en el art. 61 LDVA, consisten en multas para las infracciones muy graves de hasta 9.000 euros, para las infracciones graves de hasta 6.000 euros y para las leves de hasta 3.000 euros (cuantías éstas que, de acuerdo con lo dispuesto en la Disposición Adicional Cuarta, podrán ser revisadas y actualizadas por el Consejo de Gobierno). En ningún caso podrán imponerse multas inferiores a 1.000 euros.

Como sanciones accesorias a dichas multas, la Administración tiene la potestad de imponer: la inhabilitación de la persona jurídica o entidad infractora para promover o participar en promociones de viviendas protegidas o en actuaciones de edificación o rehabilitación con financiación pública durante el plazo máximo de tres años, en los supuestos de infracciones graves, o de seis años, en los supuestos de infracciones muy graves; y la pérdida de la condición de Agencia de Fomento del Alquiler o de entidad intermediaria homologada como agente colaborador a los efectos de esta Ley.

Los plazos de prescripción, tanto de las infracciones administrativas como de las sanciones tipificadas por la presente Ley, son de: cuatro años para las muy graves; tres años para las graves; y dos años para las leves.

Respecto al procedimiento sancionador, regulado en el art. 67, destaca el plazo máximo establecido para su conclusión, un año contado desde la notificación del acuerdo de inicio del procedimiento. El vencimiento del mismo sin que se haya notificado resolución expresa produce la caducidad del procedimiento, lo que no impide la iniciación de uno nuevo si no ha prescrito la infracción que dio lugar al mismo.

Y en cuanto a la determinación del órgano competente para iniciar, tramitar y resolver el procedimiento sancionador, la Ley dispone que corresponden, en el caso de la Administración de la Junta de Andalucía, en función de la cuantía de las multas, a la persona titular de la Secretaría General, a la persona titular de la Dirección General o a la persona titular de la Delegación Provincial o Territorial de la Consejería competente en materia de vivienda. En el ámbito de las entidades locales, se estará a lo que disponga su normativa específica. 
c) Medidas de fomento para evitar la existencia de viviendas deshabitadas.

Otra de las novedades más significativas de esta Ley es la inclusión en su art. 25 de una definición de "viviendas deshabitadas". Tras definir qué se considera "vivienda" a los efectos del nuevo Título VI de la LDVA ${ }^{22}$, describe un par de situaciones que hacen presumir que la vivienda no está habitada. La primera, cuando no se destine efectivamente al uso residencial previsto por el ordenamiento jurídico o el planeamiento urbanístico durante más de seis meses consecutivos en el curso de un año desde el último día de efectiva habitación. Y la segunda, cuando la vivienda no cuente con contrato de suministro de agua o de electricidad o presente nulo o escaso consumo de suministros, calculados con base en la media habitual de consumo por vivienda y por año. No obstante, se trata de presunciones iuris tantum, susceptibles de prueba en contrario.

Se excluyen de este concepto, las edificaciones destinadas a un uso regulado en la legislación turística, las viviendas de las personas físicas cuyo uso exclusivo sea el de esparcimiento o recreo y las viviendas que sean usadas de forma efectiva mediante su arrendamiento como fincas urbanas celebrado por temporadas.

En concordancia con el tenor del art. 53.1.a) de esta Ley, expresamente se contempla que las viviendas deshabitadas de titularidad de personas físicas no serán objeto del ejercicio de la potestad sancionadora. A tales efectos, sólo se considerará vivienda deshabitada, aquélla cuya titularidad corresponda a una persona jurídica, constituida regular o irregularmente.

La Sección $2^{a}$ del Capítulo I del Título VI regula, de acuerdo con lo establecido en la normativa de procedimiento administrativo, el procedimiento contradictorio que ha de seguirse para declarar una vivienda deshabitada.

Para el inicio del mismo, la Administración tendrá en cuenta una serie de indicios de no habitación que se explicitan en el art. 26, tales como: los datos

\footnotetext{
${ }^{22}$ Se entiende por vivienda "toda edificación que, por su estado de ejecución, cuente con las autorizaciones legales para su efectiva ocupación o que se encuentre en situación de que se soliciten las mismas y que, conforme al planeamiento urbanístico de aplicación, tenga como uso pormenorizado el residencial o tenga autorizado el uso residencial mediante la correspondiente licencia urbanística de cambio de uso, en suelo clasificado como urbano o urbanizable. Lo anterior se entenderá sin perjuicio del deber de solicitar dichas autorizaciones."
} 
del padrón de habitantes y de otros registros públicos de residentes u ocupantes; consumos anormalmente bajos o carencia de los suministros de agua, gas y electricidad, de conformidad con lo dispuesto en el Anexo de esta Ley; recepción de correo y notificaciones en otros lugares; declaraciones o actos propios de la persona titular de la vivienda; o declaraciones de los titulares de la vecindad.

Paralelamente a la regulación de este procedimiento, se han añadido también actuaciones tendentes a promover el uso social de las viviendas, el cumplimiento efectivo del destino de la vivienda al uso legalmente establecido de dar habitación e incentivar la incorporación de las viviendas deshabitadas al mercado inmobiliario.

En este contexto, el art. 43 de la Ley dispone que, a través de los Planes de Vivienda o de los Programas de Fomento aprobados por la Consejería competente en materia de vivienda, se contemplen como medidas de fomento a las personas propietarias de viviendas deshabitadas, entre otras, las siguientes: medidas de intermediación en el mercado del arrendamiento de viviendas que garanticen su efectiva ocupación; el aseguramiento de los riesgos que garanticen el cobro de la renta, los desperfectos causados y la defensa jurídica de las viviendas alquiladas; medidas fiscales que determinen las respectivas Administraciones Públicas en el ejercicio de sus competencias; y subvenciones para personas propietarias y arrendatarias y entidades intermediarias.

Evidentemente, todas estas medidas estarán en función de las disponibilidades presupuestarias.

Concretamente, el 15 de abril se ha publicado en el BOJA núm. 71 el Acuerdo del Consejo de Gobierno, de 2 de abril de 2013, por el que se formula del Plan Andaluz de Vivienda y Rehabilitación, cuyo plazo de elaboración es de ocho meses a partir del día siguiente al de la publicación del Acuerdo, por lo tanto, antes del 16 de diciembre de 2013. Habrá que esperar, pues, para comprobar cuáles de las medidas de fomento comentadas se recogerán efectivamente en el futuro Plan.

\section{Sobre la viabilidad de las medidas previstas en el Decreto-Ley 6/2013.}

Sobre la ejecución, al menos a corto plazo, de las medidas previstas en el Decreto-Ley 6/2013, detectamos una serie de escollos de tipo normativo, de medios personales y económicos. 
En primer lugar, algunas de las medidas clave reguladas en el Decreto-Ley no son de directa aplicación, sino que precisan de un desarrollo reglamentario, tales como: la elaboración de un Plan de Inspección en materia de vivienda; la creación de un Registro de Viviendas Deshabitadas; la regulación de las medidas la intermediación en el mercado del arrendamiento y del aseguramiento de los riesgos correspondientes a la ocupación de las viviendas deshabitadas; el programa de Bolsas de Viviendas en Alquiler; o la concesión de subvenciones o ayudas para el alquiler.

La Disposición Adicional Tercera del Decreto-Ley establece que el Consejo de Gobierno deberá aprobar las normas reglamentarias que permitan poner en funcionamiento el Registro de Viviendas Deshabitadas, en todo caso, en el plazo máximo de dos meses desde la entrada en vigor de esta norma.

Respecto al desarrollo normativo de las medidas de fomento contempladas en los arts. 44 y 45 LDVA, la Disposición Final Primera dispone que deberá efectuarse en el plazo de un mes a contar desde la entrada en vigor del mismo, a fin de regular un programa de Bolsas de Viviendas en Alquiler destinado a asegurar la efectiva ocupación.

Por su parte, la Disposición Final Segunda explicita que el desarrollo reglamentario del resto de las disposiciones del Decreto-Ley se llevará a efecto de acuerdo con lo dispuesto en los artículos 112 y 119.3 del Estatuto de Autonomía para Andalucía y el artículo 44 de la Ley 6/2006, de 24 de octubre, de Gobierno de la Comunidad Autónoma de Andalucía.

Desde un punto de vista procedimiental, ya se acometa el desarrollo normativo del Decreto-Ley vía Decreto u Orden, el procedimiento a seguir exige cumplir una serie de trámites preceptivos, así: una vez acordado el inicio de la tramitación de la norma, se ha de contar con diversos informes preceptivos (entre otros, el de presupuestos, de impacto de género, de la Secretaría General Técnica, etc.); se debe abrir un trámite de alegaciones y de audiencia; habrá de remitirse, en su caso, al Consejo Económico y Social; ha de emitirse informe por parte del Gabinete Jurídico de la Junta de Andalucía; cuando se trate de reglamentos ejecutivos ha de ser dictaminado por el Consejo Consultivo de Andalucía; si se trata de un Decreto, ha de aprobarse por la Comisión General de Viceconsejeros Viceconsejeras y posteriormente por el Consejo de Gobierno, y si se trata de una Orden, por el titular de la Consejería competente; y finalmente, publicarse en el Boletín Oficial de la Junta de Andalucía.

Pues bien, partiendo de la hipótesis de que se contara con los borradores de 
los proyectos de Decretos u Órdenes ya elaborados, el respeto de los plazos mínimos legalmente establecidos en el procedimiento de elaboración normativa para que se formulen alegaciones, se contesten, se emitan informes, dictámenes, etc., dificilmente hace pensable el que se cuente con ellos en los próximos meses.

No obstante lo dicho, hay que subrayar que como desarrollo del DecretoLey 6/2013, con fecha de 10 de mayo se ha aprobado por Orden de la Consejera de Fomento y Vivienda el Plan Extraordinario de Inspección de Viviendas 2013-2014 (publicado en el BOJA núm. 95, de 17 de mayo), cuyo artículo único reza así: "Se aprueba el Plan Extraordinario de Inspección de Viviendas 2013-2014". Ciertamente se ha aprobado en poco menos de un mes un Plan Extraordinario de Inspección, pero sin ni siquiera hacer referencia al contenido mínimo que se menciona en el nuevo artículo 51.5 LDVA, lo que vuelve a generar más inseguridad y desconcierto. La realidad es que tras la aprobación y publicación de esta norma se cuenta formalmente con un Plan, pero sólo eso, remitiéndose la concreción de las medidas necesarias en orden al desarrollo y ejecución de los programas de inspección al Director General de Vivienda, según dispone la Disposición Final Primera de la Orden.

En segundo término, respecto a los medios personales hay que comentar que el Decreto-Ley 6/2013 otorga un papel fundamental al Cuerpo de Inspectores (art. 27.6 LDVA).

El nuevo art. 48 LDVA atribuye, a los efectos de asegurar el efectivo derecho a la vivienda y en particular evitar la situación de viviendas deshabitadas, las funciones inspectoras correspondientes al Cuerpo de Inspección de Ordenación del Territorio, Urbanismo y Vivienda, en los términos establecidos en el Decreto 225/2006, de 26 de diciembre, por el que se aprueba el Reglamento de Organización y Funciones de la Inspección de Ordenación del Territorio, Urbanismo y Vivienda de la Junta de Andalucía, o norma que lo sustituya.

La Inspección planificará y programará su actuación según objetivos generales o particulares, en atención a su ámbito competencial material y territorial, y actúa de conformidad con lo previsto en el Plan de Inspección en materia de vivienda.

El citado Plan será aprobado mediante Orden de la persona titular de la Consejería con competencia en materia de vivienda y elaborado a partir de las propuestas que a tal efecto realicen los órganos directivos, centrales y periféricos y entidades instrumentales con incidencia en este ámbito competencial, teniendo un carácter reservado y una vigencia máxima de dos años, prorrogable 
por una anualidad. El contenido mínimo que ha componer el Plan se describe en el art. 51.5 LDVA.

Como puede comprobarse, el ejercicio de las funciones sancionadoras en materia de vivienda y para la declaración de viviendas deshabitadas recae sobre el previo trabajo desarrollado por los Inspectores del Cuerpo de Inspección de Ordenación del Territorio, Urbanismo y Vivienda (A1.6). Pues bien, desde que se creara el citado Cuerpo por la Disposición Adicional Cuarta de la Ley $13 / 2005$, de 11 de noviembre, y se procediera a una primera convocatoria excepcional para cubrir por concurso de mérito entre funcionarios pertenecientes a Grupo A un número reducido de plazas de Inspectores, sólo se ha convocado un único proceso selectivo mediante oposición, por Orden de 17 de noviembre de 2008, de la Consejería de Justicia y Administración Pública (BOJA núm. 240 de 3 diciembre), para acceder a "once plazas" como funcionarios de carrera en el citado Cuerpo.

Ante esta realidad, es más que previsible que se tenga que hacer uso de la previsión "excepcional" contenida en la Disposición Adicional Sexta, la cual contempla la posibilidad de que "las funciones inspectoras en materia de vivienda atribuidas a los Inspectores o Inspectoras del Cuerpo Superior de Inspección de Ordenación del Territorio, Urbanismo y Vivienda puedan, excepcionalmente, en caso de ser necesario, ser realizadas por personal funcionario expresamente habilitado para el ejercicio de actuaciones inspectoras en materia de vivienda, quienes, para el ejercicio de sus funciones, tendrán la condición de agente de la autoridad y disfrutarán de las facultades y deberes legales previstos en el Decreto 225/2006, (...). La habilitación podrá ser revocada en cualquier momento."

Hasta el momento, las funciones desarrolladas por los inspectores del citado Cuerpo únicamente han girado en torno al cumplimiento de la legalidad territorial y urbanística, de conformidad con los objetivos y criterios recogidos en los Planes Generales aprobados de Inspección de Ordenación del Territorio y Urbanismo para el bienio 2007-2008, el cuatrienio 2009-2012 y el cuatrienio 2013-2016.

En el último Plan General de Inspección recién aprobado, por Orden de la Consejería de Agricultura, Pesca y Medio Ambiente de 11 de abril de $2013^{23}$

23 Tras los resultados de las últimas elecciones autonómicas, y de acuerdo con lo dispuesto en los arts. 9 y 10 del Decreto del Presidente 3/2012, de 5 de mayo, de la Vicepresidencia y sobre reestructuración 
no se contemplan, como tampoco en los dos anteriores, ninguna medida inspectora en relación con las viviendas.

Ha sido la recién publicada Orden de la Consejería de Fomento y Vivienda de 10 de mayo de 2013, la primera en aprobar un Plan de Inspección de Viviendas, aunque con carácter extraordinario, para, en principio, la anualidad 2013-2014. En el preámbulo de esta Orden se dice que en el plazo de un año desde la aprobación del mentado Plan Extraordinario deberá aprobarse el Plan de Inspección de Vivienda.

Y por último, con relación al Cuerpo de Inspectores, si éstos -suponemosestán integrados en la Relación de Puestos de Trabajo correspondiente a la Dirección General de Urbanismo, dependiente de la Secretaría General de Ordenación del Territorio, de acuerdo con lo dispuesto en el Decreto 151/2012, de 5 de junio, por el que se establece la estructura orgánica de la Consejería de Agricultura, Pesca y Medio Ambiente, debería articularse la adscripción de al menos algunos de estos Inspectores a la Dirección General de Vivienda, dado que de acuerdo con el art. 8.3 del Decreto 150/2012, de 5 de junio, por el que se establece la estructura orgánica de la Consejería de Fomento y Vivienda, le corresponden a ésta las funciones de inspección en materia de vivienda.

$\mathrm{Y}$ en tercer lugar, apreciamos el gran inconveniente de tipo económico que supone el materializar las medidas previstas en el Decreto-Ley 6/2013.

Para poder realizar las labores de inspección que se prevén en el DecretoLey se necesitará aumentar el Cuerpo de Inspectores y formar y dotar suficientemente a un gran número de funcionarios para que puedan colaborar con aquéllos en la realización de los seguimientos de consumos de agua y luz de las viviendas, en las labores de información sobre la titularidad de los inmuebles, comprobación de los periodos de desocupación de la vivienda para determinar si exceden el límite permitido por la norma, etc. Y todo ello sin perder de vista que en Andalucía hay más de cuatro millones y medio de viviendas.

Por otra parte, en el caso de las expropiaciones temporales, una parte del justiprecio al banco expropiado lo abona la Junta de Andalucía, la cual, para-

de Consejerías, se establece que las competencias en materia de planificación y ordenación territorial y urbanismo que hasta entonces venía ejerciendo la Consejería de Obras Públicas y Vivienda pasan a corresponder a la Consejería de Agricultura, Pesca y Medio Ambiente. 
dójicamente les debe, según el Informe Anual de la Cámara de Cuentas de Andalucía sobre Fiscalización de la Cuenta General, Contratación Administrativa y Fondo de Compensación Interterritorial de la Junta de Andalucía correspondiente al ejercicio 2011, más de 467,77 millones de euros ${ }^{24}$. Asimismo, es como poco curioso el dato de que la Ley de Presupuestos de la Junta de Andalucía para 2013 contempla, entre sus operaciones de endeudamiento para el sector público empresarial andaluz una autorización para contraer préstamos con entidades financieras públicas y privadas hasta el límite de 150 millones de euros, con lo que pudiera llegarse a la situación de que se formalice un crédito con un banco que, a la vez, sirviera para pagar el justiprecio de la expropiación temporal de las viviendas.

Asimismo, respecto al establecimiento de incentivos fiscales o la concesión de subvenciones para las personas propietarias y arrendatarias y para entidades intermediarias, con la finalidad de fomentar el acceso a la vivienda mediante la puesta en arrendamiento de las viviendas deshabitadas, los arts. 46 y 47 LDVA contemplan, respectivamente, que la Administración podrá adoptarlas teniendo en cuenta las disponibilidades presupuestarias que para cada ejercicio establezcan las cuentas públicas.

En definitiva, nuevamente habrá que esperar a la aprobación del futuro Plan Andaluz de Vivienda para ver si se incorpora finalmente alguno de estos incentivos.

\section{ANÁLISIS DE OTRAS MEDIDAS EXISTENTES PARA PA- LIAR LOS DESAHUCIOS}

\section{El Real Decreto-Ley 27/2012, de 15 de noviembre, de Medi- das Urgentes para reforzar la Protección a los Deudores Hi- potecarios.}

El 16 de noviembre de 2012 entró en vigor el Real Decreto-Ley 27/2012, de 15 de noviembre, por el que se establecen una serie de Medidas Urgentes para reforzar la protección de los Deudores Hipotecarios, dictado al amparo de las competencias exclusivas del Estado de acuerdo con el art. 149.1.1 ${ }^{\mathrm{a}}, 6^{\mathrm{a}}$, $8^{\mathrm{a}}, 11^{\mathrm{a}}, 13^{\mathrm{a}}$ y $14^{\mathrm{a}} \mathrm{CE}$.

\footnotetext{
${ }^{24}$ Vid. el Informe Anual correspondiente al ejercicio 2011, aprobado por el Pleno de la Cámara de Cuentas de Andalucía en su sesión celebrada el 20 de febrero de 2013, en http://www.ccuentas.es.
} 
El objetivo principal de esta norma consiste en el establecimiento de una medida que permita la suspensión inmediata y por un plazo de dos años de los desahucios de las familias que se encuentren en una situación de especial riesgo de exclusión, siendo de aplicación a los procesos judiciales o extrajudiciales de ejecución hipotecaria que se hubieran iniciado a la entrada en vigor de la misma, en los que no se hubiese ejecutado el lanzamiento.

En concreto, para que un deudor hipotecario se encuentre en el ámbito de aplicación de este Real Decreto-Ley será necesario que cumpla dos tipos de requisitos: por una parte, estar incluido dentro de alguno de los colectivos sociales que se consideran de especial vulnerabilidad (las familias numerosas, las familias monoparentales con dos hijos a cargo, las que tienen un menor de tres años o algún miembro discapacitado o dependiente, o en las que el deudor hipotecario se encuentre en situación de desempleo y haya agotado las prestaciones sociales o las víctimas de violencia de género); y por otra parte, de tipo económico, de manera que los ingresos de la familia no superen el límite de tres veces el Indicador Público de Renta de Efectos Múltiples y que, además, en los cuatro años anteriores al momento de la solicitud, la unidad familiar haya sufrido una alteración significativa de sus circunstancias económicas, en términos de esfuerzo de acceso a la vivienda.

En definitiva, con esta medida, calificada de muy positiva en el Informe anual del Defensor del Pueblo Andaluz correspondiente a $2012^{25}$, se impide el lanzamiento y se garantiza que durante dos años los deudores hipotecarios especialmente vulnerables no puedan ser desalojados de sus viviendas, con la confianza de que, a la finalización de este período, habrán superado la situación de dificultad en que se puedan encontrar en el momento actual.

Por otra parte, la Disposición Adicional Única del Real Decreto-Ley 27/2012 encomienda al Gobierno para que emprenda inmediatamente las medidas necesarias para impulsar, con el sector financiero, la constitución de un Fondo Social de Viviendas destinadas a ofrecer cobertura a aquellas personas que hayan sido desalojadas de su vivienda habitual por el impago de un préstamo hipotecario, facilitándose a estas personas el acceso a contratos de arrendamiento con rentas asumibles en función de los ingresos que perciban. De esta manera, se logra favorecer el acceso a la vivienda a familias necesitadas y, al mismo tiempo, se moviliza un amplio parque de viviendas, propiedad de las entidades de crédito.

25 Vid. BOPA núm. 200, de 13 de abril de 2013, pág. 96. 


\section{La Sentencia del Tribunal de Justicia de la Unión Europea (Sala Primera), de 14 de marzo de 2013.}

La Sentencia del Tribunal de Luxemburgo de 14 de marzo de 2013, mediante la que se da respuesta a dos cuestiones prejudiciales presentadas por un juez mercantil de Barcelona, supone una magnífica baza en manos de los jueces españoles para poder paralizar los desahucios.

La Sentencia establece, por una parte, que algunos aspectos de la Ley Hipotecaria española aplicados para ejecutar el desalojo de sus casas de miles de personas durante los últimos años no son compatibles con la Directiva 93/13/CEE, del Consejo, de 5 de abril de 1993, sobre las cláusulas abusivas en los contratos celebrados con consumidores ${ }^{26}$, de modo que, a partir de ahora, los jueces que estén analizando si hay cláusulas abusivas en un contrato hipotecario podrán suspender cautelarmente el procedimiento de ejecución e impedir un desalojo ${ }^{27}$.

En este contexto, el Tribunal de Justicia de la Unión Europea fija una serie de principios sobre cómo deben interpretar los jueces nacionales si una cláusula es abusiva.

En este orden de cosas, subrayar cómo los jueces españoles, con invocación de la comentada Sentencia, han comenzado a hacer uso inmediato de la opción de decretar como medida cautelar la suspensión de los desalojos de viviendas mientras verifican si el banco había impuesto alguna cláusula abusiva en el contrato de préstamo. La primera actuación en este sentido llegó de un juez de Lanzarote.

${ }^{26} \mathrm{El}$ art. 3 de la Directiva 93/13/CEE establece:

"1. Las cláusulas contractuales que no se hayan negociado individualmente se considerarán abusivas si, pese a las exigencias de la buena fe, causan en detrimento del consumidor un desequilibrio importante entre los derechos y obligaciones de las partes que se derivan del contrato.

2. Se considerará que una cláusula no se ha negociado individualmente cuando haya sido redactada previamente y el consumidor no haya podido influir sobre su contenido, en particular en el caso de los contratos de adhesión. (...)

3. El Anexo de la presente Directiva contiene una lista indicativa y no exhaustiva de cláusulas que pueden ser declaradas abusivas".

${ }^{27}$ En anteriores ocasiones el Tribunal de Justicia de la Unión Europea ya había subrayado que el juez nacional debe apreciar de oficio el carácter abusivo de una cláusula contractual incluida en el ámbito de aplicación de la Directiva y, así, subsanar el desequilibrio existente entre el consumidor y el profesional, vid. Sentencias de 4 de junio de 2009, Pannon GSM (C-243/08), y de 14 de junio de 2012, Banco Español de Crédito (C-618/10). 
Por último, a nivel nacional destaca lo pionero de la Resolución dictada por la Audiencia Provincial de Burgos, el 18 de abril de 2013, para evitar que se produzcan desahucios injustos y dar garantías a los afectados en procesos hipotecarios. En ella se establece que no podrá señalarse ninguna subasta, ni celebrarse ningún lanzamiento hipotecario sin que previamente se haya analizado y valorado por el juez la posibilidad de que en la escritura de hipoteca existan cláusulas "nulas, ilícitas o abusivas". Como primera medida de actuación contempla la paralización de los cuarenta y siete procedimientos de ejecución hipotecaria que se encuentran en trámite, de modo que se estudiará cada uno de ellos para ver si existe algún tipo de abuso. Cada juez tendrá libertad de criterio para interpretar la Ley, a la vez que todos deberán seguir unos criterios de uniformidad.

\section{La Ley 1/2013, de 14 de mayo, de Medidas para reforzar la Protección a los Deudores Hipotecarios, Reestructuración de Deuda y Alquiler Social.}

El que fuera conocido como Proyecto de Ley Antidesahucios, ha sido finalemente aprobado por el Congreso de los Diputados el pasado 14 de mayo como Ley 1/2013, de Medidas para reforzar la Protección a los Deudores Hipotecarios, Reestructuración de Deuda y Alquiler Social (BOE núm. 116, de 15 de mayo de 2013). Esta norma pretende fundir el Real Decreto-Ley 27/2012, la iniciativa legislativa ciudadana presentada sobre la dación en pago y parte de las enmiendas presentadas por los grupos parlamentarios.

El texto de la Ley 1/2013 ajusta su contenido al fallo de la Sentencia del Tribunal de Justicia de la Unión Europea de 14 de marzo de 2013 y, en dicha línea, introduce mejoras en el mercado hipotecario a través de la modificación de la Ley Hipotecaria (cuyo Texto Refundido fue aprobado por el Decreto de 8 de febrero de 1946), la Ley 2/1981, de 25 de marzo, de Regulación del Mercado Hipotecario y la Ley $41 / 2007$, de 7 de diciembre, por la que se modifica la Ley 2/1981 y otras normas.

De las medidas contempladas en la Ley destacan las siguientes:

Los jueces podrán suspender de forma inmediata y por un plazo de dos años los desahucios de las familias que se encuentren en una situación de especial riesgo de exclusión, afectando a cualquier proceso judicial o extrajudicial de ejecución hipotecaria por el que se adjudique al acreedor la vivienda habitual de personas pertenecientes a determinados colectivos de especial vulnerabilidad y en las circunstancias económicas previstas en el art. 1 de esta Ley. 
Para estos deudores especialmente vulnerables se prevé, asimismo, que la deuda que no haya podido ser cubierta con la vivienda habitual no devengue más interés de demora que el resultante de sumar a los intereses remuneratorios un $2 \%$ sobre la deuda pendiente.

Para las hipotecas constituidas sobre vivienda habitual, se añade un tercer párrafo en el art. 114 de la Ley Hipotecaria por el que se limitan los intereses de demora de préstamos o créditos que pueden exigir las entidades de crédito a tres veces el interés legal del dinero, ahora en el 4\%, de forma que pasarán del 18,7\% al 12\%, y sólo podrán devengarse sobre el principal pendiente de pago.

Se introducen también importantes modificaciones en el procedimiento de subastas de las viviendas adjudicadas regulado en el art. 129 de la Ley Hipotecaria, de forma que el afectado pueda reducir su deuda con la vivienda y que no se produzcan desequilibrios en la tasación original. Se establece que el valor de tasación a efectos de subastas no podrá ser inferior al 75\% de la tasación que sirvió para conceder el préstamo, lo que supondría rebajar aún más la deuda pendiente del hipotecado.

En el supuesto de que la subasta quedara desierta, el banco tendrá que quedarse con el inmueble a un precio mínimo del $70 \%$ del valor original si se trata de vivienda habitual. Y si en el plazo de diez años consigue venderla con beneficios, la mitad de esas plusvalías se destinarán a cubrir parte de la deuda del cliente, empezando por el capital principal y terminando por los intereses de demora, de forma que primero se reduzca el grueso de la deuda y los intereses no la sigan aumentando.

Aunque no se incluye la aprobación de la dación en pago con carácter universal y retroactivo, introduce modificaciones en la actual Ley Hipotecaria y en la Ley 1/2000, de 7 de enero, de Enjuiciamiento Civil que suponen grandes recortes en la deuda de los desahuciados. Concretamente, en el caso de que se produzca la ejecución de la vivienda habitual hipotecada y el remate aprobado fuera insuficiente para lograr la completa satisfacción del derecho del ejecutante, la ejecución se ajustará a las siguientes reglas: el ejecutado quedará liberado de su responsabilidad si abona el $65 \%$ de la cantidad que hubiere quedado pendiente en el plazo de cinco años, o si satisficiera el 80\% en el plazo de diez años.

También se ha incorporado la modificación del procedimiento ejecutivo consistente en que el órgano judicial competente, de oficio o a instancia de par- 
te, pueda apreciar la existencia de cláusulas abusivas en el título ejecutivo y, por ende, decretar la improcedencia de la ejecución o su continuación sin la aplicación de aquéllas que sean consideradas abusivas.

En los supuestos de venta extrajudicial se incluye la posibilidad de que el Notario pueda suspenderla cuando las partes acrediten que han solicitado ante el órgano judicial competente que dicte resolución declarando la improcedencia de dicha venta, con base en la existencia de cláusulas abusivas en el contrato de préstamo hipotecario, o su continuación sin la aplicación de las mismas. El Notario podrá, en su caso, advertir a las partes de la posibilidad de alguna cláusula de este tipo en el contrato.

Por último, la Disposición Adicional Primera recoge el mandato de constitución de un Fondo Social de Viviendas destinado a ofrecer cobertura a aquellas personas que hayan sido desalojadas de su vivienda habitual por el impago de un préstamo hipotecario.

\section{El Real Decreto $233 / 2013$, de 5 de abril, por el que se regula el Plan Estatal de fomento del alquiler de viviendas, la reha- bilitación edificatoria, y la regeneración y renovación urbanas, 2013-2016.}

Tal y como recoge la Exposición de Motivos del Real Decreto 233/2013, de 5 de abril, por el que se regula el Plan Estatal de fomento del alquiler de viviendas, la rehabilitación edificatoria, y la regeneración y renovación urbanas para el periodo 2013-2016, este Plan se enmarca dentro del Programa Nacional de Reformas del Gobierno de España para contribuir al impulso del crecimiento y la competitividad de la economía española, junto con otras iniciativas legislativas que en la actualidad se están tramitando (cita a la Ley de Medidas de Flexibilización y Fomento del Alquiler de Viviendas y el Anteproyecto de Ley de rehabilitación, regeneración y renovación urbana).

Los objetivos del Plan son, fundamentalmente, los siguientes: adaptar el sistema de ayudas a las necesidades sociales actuales y a la escasez de recursos disponibles, concentrándolas en dos ejes, el fomento del alquiler y el fomento de la rehabilitación y regeneración y renovación urbanas; contribuir a que los deudores hipotecarios para la adquisición de una vivienda protegida puedan hacer frente a las obligaciones de sus préstamos hipotecarios; reforzar la cooperación y coordinación interadministrativa, así como fomentar la corresponsabilidad en la financiación y en la gestión; mejorar la calidad de la edificación; y contribuir a la reactivación del sector inmobiliario, desde las 
actuaciones de fomento del alquiler y de apoyo a la rehabilitación de edificios y a la regeneración urbana ${ }^{28}$.

Entre los objetivos sustantivos del Plan destaca su vocación social, la apuesta por el fomento del alquiler como una de las fórmulas más adecuadas para la satisfacción de las necesidades actuales de vivienda de un numeroso sector de la ciudadanía. A este respecto se establecen: ayudas al alquiler que beneficiarán a aquellos que más lo precisen en función de la renta de los miembros de la unidad familiar; se limita la cuantía de los alquileres que se financian, evitando la subvención de alquileres elevados; y se financia una proporción del alquiler, sin asignar una cuantía fija, para evitar situaciones de generación de rentas adicionales superiores a las del propio alquiler.

Destaca la incorporación de un nuevo programa que pretende comprometer a las Administraciones públicas en la generación de un parque público de viviendas que pueda servir para crear una oferta en alquiler. Se busca con este programa ofrecer una solución para los casos más extremos en los que no se alcanza, entre todos los miembros del hogar, ni siquiera un umbral mínimo de rentas, vinculando esta posibilidad de ayuda al alquiler con la intervención de los servicios sociales, de forma que el acceso a la vivienda sea una parte de un tratamiento de carácter integral.

El programa de subsidiación de préstamos convenidos mantiene estas ayudas ante la creciente dificultad de las familias para poder afrontar el cumplimiento de las obligaciones de los préstamos hipotecarios que suscribieron para la adquisición de una vivienda protegida, en coherencia, además, con lo dispuesto del Real Decreto-ley 6/2012, de 9 de marzo, de Medidas Urgentes de Protección de Deudores Hipotecarios sin recursos.

Los restantes programas del Plan giran en torno a la rehabilitación y la regeneración y renovación urbanas.

\footnotetext{
${ }^{28}$ Para la consecución de sus objetivos, el Plan se estructura en los siguientes Programas:

1. Programa de subsidiación de préstamos convenidos.

2. Programa de ayuda al alquiler de vivienda.

3. Programa de fomento del parque público de vivienda de alquiler.

4. Programa de fomento de la rehabilitación edificatoria.

5. Programa de fomento de la regeneración y renovación urbanas.

6. Programa de apoyo a la implantación del informe de evaluación de los edificios.

7. Programa para el fomento de ciudades sostenibles y competitivas.

8. Programa de apoyo a la implantación y gestión del Plan.
} 
Como en los Planes anteriores, la gestión de las ayudas del Plan estatal corresponderá a las Comunidades Autónomas y Ciudades de Ceuta y Melilla. La colaboración entre ellas y el Ministerio de Fomento se instrumentará mediante los Convenios correspondientes pero, a diferencia de los Planes anteriores, y con el propósito de fomentar la corresponsabilidad, se da preferencia a las actuaciones cofinanciadas.

Por último, destacar el tenor de las Disposiciones Adicionales Primera y Segunda del Real Decreto 233/2013, muy a tener en cuenta por las Administraciones autonómicas, ya que, la primera, posibilita la no transferencia de fondos procedentes del nuevo Plan Estatal a las Comunidades Autónomas o Ciudades de Ceuta y de Melilla cuando éstas no se encuentren al corriente de las justificaciones de la aplicación y el pago de todas las cantidades ya transferidas en ejecución de Planes Estatales de Vivienda anteriores. Y la segunda, faculta a la Administración General del Estado para realizar las compensaciones que correspondan, cuando coexista una obligación de reintegro que deban cumplir las Comunidades Autónomas y Ciudades de Ceuta y Melilla y una obligación de transferencia que competa al Ministerio de Fomento, permitiendo que la misma opere en supuestos pertenecientes a distintos Programas del Plan, e incluso a distintos Planes de Vivienda.

\section{La Ley $4 / 2013$, de 4 de junio, de Medidas de Flexibilización y Fomento del Mercado del Alquiler de Viviendas.}

En la misma línea que el recién aprobado Plan Estatal de Vivienda para el período 2013-2016 se situaba el Proyecto de Ley de Medidas de Flexibilización y Fomento del Mercado del Alquiler de Viviendas, finalmente aprobado como Ley 4/2013, el 4 de junio.

El principal objetivo de esta norma es el de flexibilizar el mercado del alquiler para lograr la necesaria dinamización del mismo, por medio de la búsqueda del necesario equilibrio entre las necesidades de vivienda en alquiler y las garantías que deben ofrecerse a los arrendadores para su puesta a disposición del mercado arrendaticio. Para lograr dicho propósito se procede a la modificación de diversos preceptos de la Ley 29/1994, de 24 de noviembre, de Arrendamientos Urbanos, en el sentido de: reforzar la libertad de pactos y dar prioridad a la voluntad de las partes en el contrato de arrendamiento; reducir de cinco a tres años la prórroga obligatoria del contrato de arrendamiento y de tres a uno la prórroga tácita, de manera que arrendadores y arrendatarios puedan adaptarse con mayor facilidad a eventuales cambios en sus circunstancias personales; posibilitar la recuperación del inmueble por el arrendador, para 
destinarlo a vivienda permanente en determinados supuestos, que requiere que hubiera transcurrido al menos el primer año de duración del contrato, sin necesidad de previsión expresa en el mismo; y prever que el arrendatario pueda desistir del contrato en cualquier momento, una vez que hayan transcurrido al menos seis meses y lo comunique al arrendador con una antelación mínima de treinta días.

En definitiva, se pretende normalizar el régimen jurídico del arrendamiento de viviendas, protegiendo los derechos tanto del arrendador como del arrendatario e incentivando el alquiler como una opción viable y alternativa útil a la compra de una vivienda.

\section{CONGLUSIONES}

El art. 33 de nuestra Constitución garantiza un instituto, el de la propiedad privada, que detenta un lugar central en el orden económico-social español, al igual que en el resto de los Estados de la Unión Europea, y que se expresa tanto en el reconocimiento del derecho a la propiedad privada, como en la reserva de ley para la delimitación de su contenido de acuerdo con su función social, como en la llamada garantía expropiatoria.

El Ejecutivo de la Comunidad Autónoma de Andalucía, en el actual contexto que se padece de grave crisis económica y social y con el propósito de asegurar el derecho a la vivienda de las personas más vulnerables, fundamentalmente, aquellas que están inmersas en procesos de desahucios, ha dictado el Decreto-Ley 6/2013, por el que se procede a delimitar el contenido esencial del derecho de propiedad de la vivienda.

Ha modificado la Ley del Derecho a la Vivienda en Andalucía, cuyo art. 1.3 preceptúa que forma parte del referido contenido "el deber de destinar de forma efectiva el bien al uso habitacional previsto por el ordenamiento jurídico, así como mantener, conservar y rehabilitar la vivienda con los límites y condiciones que así establezca el planeamiento y la legislación urbanística."

Para paliar el drama social de los desahucios, dar efectividad al derecho a disfrutar de una vivienda digna y proteger el derecho a la vida y a la integridad física y psíquica de las personas, ha regulado una serie de medidas, la más polémica y drástica, la expropiación temporal del uso de viviendas a los bancos y sus filiales inmobiliarias, cuya legalidad está siendo estudiada por la propia Comisión Europea por su incompatibilidad con los compromisos adquiri- 
dos por España para recibir la ayuda financiera europea, contemplados en el Memorándum del rescate bancario.

A lo largo de estas páginas hemos reflexionado sobre el instrumento empleado por la Comunidad Autónoma de Andalucía para acometer estas importantes modificaciones normativas, la competencia esgrimida para ello, sobre el contenido de las principales medidas adoptadas, los inconvenientes para ser acometidas -al menos a corto plazo- y la existencia de otras medidas e instrumentos menos gravosos y más proporcionados para conseguir el mismo objetivo.

Siendo totalmente loable el fin que se pretende conseguir, no nos merece el mismo juicio la vía elegida así como algunos de los medios propuestos. El uso del Decreto-Ley para introducir en el ordenamiento jurídico una regulación de tal calado, en la que se procede a delimitar la función social de la propiedad y se introduce un tipo de expropiación temporal del uso de viviendas a los bancos, es un cauce por el que priva al Parlamento de debatir en su seno temas de suma trascendencia. Asimismo, el resultado de una norma sorpresiva, ya que en su procedimiento de elaboración ha faltado la audiencia y participación de los sectores implicados (entidades bancarias y resto de agentes sociales), acarrea que ésta adolezca del consenso y acuerdo necesarios.

Ciertamente, la situación de angustia que padecen muchas familias andaluzas desahuciadas de sus viviendas constituye una situación extremadamente preocupante, pero esta terrible realidad no es nueva ni específica de nuestra Comunidad. Prueba de ello es el Real Decreto-Ley 27/2012, de 15 de noviembre, que aprobó el Gobierno de España y que posibilita desde entonces la suspensión inmediata de los desahucios de familias en situación de vulnerabilidad por un periodo de hasta dos años, medida ésta incorporada junto con otras en la Ley 1/2013, de 14 de mayo, de Medidas para Reforzar la Protección de los Deudores Hipotecarios, Reestructuración de Deuda y Alquiler Social.

Por otra parte, el que cada Comunidad Autónoma legisle y determine el contenido esencial de la propiedad y su función social de manera distinta genera una situación de inseguridad jurídica y desigualdad entre los españoles. Y, desde un punto de vista económico, puede representar un desincentivo para la inversión en nuestra Comunidad, ya que los bancos y empresarios pueden percibir que los activos de sus empresas peligren en nuestro territorio, por lo que decidan invertir en otros. 
Por los motivos expuestos, consideramos, por una parte, que debiera procederse por una Ley estatal a la delimitación del contenido esencial de la propiedad y a la determinación de la función social de la vivienda, de forma uniforme para todas las Comunidades Autónomas, con base en las competencias exclusivas que el art. 149.1 de la Constitución atribuye al Estado. Y, por otra parte, entendemos que, con base en las medidas aprobadas por el Gobierno de España desde noviembre que permiten paralizar los desahucios, los pronunciamientos de la Sentencia de 14 de marzo de 2013 del Tribunal de Justicia de la Unión Europea -aplicados de inmediato por los jueces y Tribunales españoles- y las Leyes recientemente aprobadas sobre reforzamiento de la protección a los deudores hipotecarios y de fomento del alquiler, la medida expropiatoria introducida por el Decreto-Ley 6/2013 no resulta proporcionada a la consecución del objetivo previsto, existiendo en la actualidad otras menos restrictivas del contenido esencial del derecho fundamental a la propiedad privada y, a su vez, menos costosas y de aplicación inmediata ya que, como hemos puesto de relieve, el comentado Decreto-Ley precisa para su aplicación de un desarrollo normativo inexistente y de unos medios personales y económicos para realizar la imprescindible labor de inspección más que escasos.

En definitiva, consideramos que las limitaciones o restricciones en el ejercicio de los derechos fundamentales han de ser las estrictamente indispensables y, por consiguiente, abogamos por que las Administraciones con competencias en materia de vivienda, esto es, las Comunidades Autónomas, hagan uso de la medida de suspensión de los desahucios ya existente, constituyan Bolsas de Viviendas en Alquiler, velen porque no permanezca desocupada ninguna vivienda de titularidad pública, potencien los alojamientos transitorios y promuevan las viviendas protegidas que sean necesarias, contando para ello con los datos que proporcionan instrumentos tan valiosos como los Registros Públicos de Demandantes de Viviendas Protegidas y los Planes Municipales de Vivienda y Suelo. 